\title{
A temática dos movimentos sociais urbanos no Brasil dos anos 1970/80*
}

Marco Antonio Perruso**

Resumo: Durante as décadas de 1970 e 1980, uma parcela significativa do campo intelectual brasileiro voltouse privilegiadamente para a investigação dos movimentos populares, entre eles, os movimentos sociais urbanos. Tal processo comportou grande ênfase no caráter inovador de tais movimentos, em contraste com o que seriam seus homólogos do período pré-64. A disseminação desses estudos apontava para a renovação de nossa cultura política historicamente fundada na desigualdade, agora abalada pelo reconhecimento da entrada em cena de novos atores coletivos. Diante de tal desafio analítico, o pensamento social brasileiro de então protagonizou uma inflexão fenomenológica, buscando interpretar aqueles movimentos sob a perspectiva de sua autoconstrução, em detrimento da primazia de fatores estruturais que os condicionariam.

Palavras-chave: Movimentos sociais urbanos; Intelectuais; Pensamento social brasileiro.

Abstract: During the 1970s and 1980s an important part of the Brazilian intellectual field began to focus on research the popular movements, including urban social movements. This process involved a great emphasis on the innovative nature of these movements, in contrast with their counterparts of the pre-64. The spread of these studies pointed to the renewal of our political culture, historically founded on inequality, now shaken by the recognition of the entrance of new collective actors. Faced with this analytical challenge, the Brazilian social thought of period experienced a phenomenological inflection, seeking to interpret these movements from the perspective of self-construction, rather than the primacy of structural factors that determine them.

Keywords: Urban social movements; Intellectuals, Brazilian social thought.

É conhecida a grande repercussão que o renascimento do movimento sindical e demais movimentos sociais no Brasil de meados dos anos 1970 provocou no pensamento social brasileiro. Grande parte dos intelectuais atuantes na época destacou esse renascimento como uma importante novidade para o país. Foi desenvolvida, concomitantemente, uma leva de estudos sobre movimentos populares, sindicatos, associações de moradores etc., que movimentaram as ciências sociais brasileiras. Tais estudos trouxeram um leque de novos problemas analíticos, novas questões teóricas, novos desafios empíricos, além de se debruçarem sobre nossa trajetória histórica. Os intelectuais dedicados à pesquisa do "novo sindicalismo" e dos "novos" movimentos sociais urbanos procuravam, muitas vezes engajando-se politicamente nesses mesmos movimentos, traduzir as diversas experiências de lutas dos "de baixo". Renovavam, assim, o debate intelectual sobre a sociedade civil e a democracia brasileira. No que tange ao escopo do presente trabalho, interessa registrar que naquele contexto emergiu o campo de estudos sobre os

\footnotetext{
* Este artigo foi extraído de minha tese de doutorado Em Busca do "Novo": Intelectuais Brasileiros e Movimentos Populares nos Anos 1970/80 (PPGSA/IFCS/UFRJ, Rio de Janeiro, 2008, 540 p.), posteriormente publicada em livro, em versão condensada, com o mesmo título (São Paulo: Annablume, 2009, 283 p.).

** Universidade Federal Rural do Rio de Janeiro. E-mail: trogao@bol.com.br.
} 
movimentos sociais urbanos no Brasil, que se consolidou nos anos 1980. Este artigo busca retomar o desenvolvimento dessa temática no campo intelectual brasileiro do período, notadamente o centrado no eixo Rio-São Paulo.

MOVIMENTOS SOCIAIS URBANOS E SUA EMERGÊNCIA NO BRASIL DA SEGUNDA METADE DO SÉC. $X X^{1}$

Os movimentos sociais urbanos podem ser definidos previamente como articulações da sociedade civil voltadas para temáticas vinculadas não ao universo do trabalho, mas às demais e diversas dimensões da vida da população urbana.

Eles inserem-se na dinâmica social do capitalismo moderno, refletem as desigualdades de consumo individual e coletivo e a correlata escassez de serviços urbanos básicos que atinge os setores mais pobres da população. ${ }^{2}$ Tais serviços incluem diversos bens e equipamentos coletivos, normalmente providos pelo Estado, junto ao qual se desenvolvem majoritariamente os processos reivindicativos e conflitivos provindos dos movimentos sociais urbanos, ainda que frequentemente a percepção das carências urbanas ocorra inicialmente no plano individual. ${ }^{3}$ Minoritariamente, tais serviços são prestados por empresas privadas concessionárias, não sendo mais o caso de serviço público, mas concessão pública para a iniciativa privada, situação em que os movimentos sociais urbanos dialogam com outro "oponente": uma empresa determinada ou um conjunto de empresas do mesmo ramo (de ônibus, do ramo imobiliário etc.).

Mais amplamente, no âmbito da "organização coletiva do modo de vida", os movimentos sociais urbanos referem-se à resistência e à luta contra as condições precárias em que grande parte dos setores populares convive; ${ }^{4}$ e pelo "direito a uma vida melhor", 5 isto é, pelo "atendimento de novas necessidades", configurando "uma luta pela ampliação do acesso ao espaço político e aos benefícios do desenvolvimento econômico". 6

0 rápido crescimento urbano e industrial, especialmente em cidades de países subdesenvolvidos, produziu e continua a produzir condições precárias de vida, tendo em vista igualmente o correlato crescimento econômico, que normalmente se dá com

\footnotetext{
${ }^{1}$ Introduzo e desenvolvo a temática dos movimentos sociais urbanos, bem como a literatura pertinente, lançando mão de alguns dos próprios trabalhos pioneiros no Brasil, quase sempre de autoria de pesquisadores e professores de universidades públicas de São Paulo e Rio de Janeiro.

${ }^{2}$ SINGER, Paul. Movimentos de Bairro. In: SINGER, Paul; BRANT, Vinícius Caldeira (orgs.). São Paulo: o Povo em Movimento. 1. ed. Rio de Janeiro: Vozes/CEBRAP, 1980, p. 83-107 (p. 83/85).

${ }^{3}$ GOHN, Maria da Glória. Reivindicações Populares Urbanas. 1a ed. São Paulo: Autores Associados/Cortez, 1982. p. 9-10 e 30. MOISÉS, José Álvaro e MARTINEZ-ALIER, Verena. A Revolta dos Suburbanos ou "Patrão, o Trem Atrasou". In: MOISÉS, José Álvaro et alii. Contradições Urbanas e Movimentos Sociais. 1. ed. Rio de Janeiro: CEDEC/Paz e Terra, 1978, p. 13-63 (p. 50).

${ }^{4}$ Ibidem, p. 13.

${ }^{5}$ CARDOSO, Ruth C.L. Movimentos Sociais Urbanos: Balanço Crítico. In: SORJ, Bila e ALMEIDA, Maria Hermínia Tavares de (org.). Sociedade e Política no Brasil Pós-64. 1. ed. São Paulo: Brasiliense, 1983. p. 215-239 (p. $216-7$.

${ }^{6}$ DURHAM, Eunice. Movimentos Sociais, a Construção da Cidadania. Novos Estudos CEBRAP. São Paulo: n. 10, p. 4-30, 1984 (p. 25). JACOBI, Pedro. Movimentos Populares Urbanos e Resposta do Estado: utonomia e Controle vs. Cooptação e Clientelismo. In: BOSCHI, Renato Raul (org.). Movimentos Coletivos no Brasil Urbano. 1a ed. Rio de Janeiro: Zahar, 1983, p. 145-179 (p. 147).
} 
significativa concentração de renda. Esse processo inclui a inserção urbana de novas camadas populares - que migraram para as cidades - a partir da primeira metade do século XX, se acelerando desde os anos 1950.

A questão da reprodução da força de trabalho, aqui presente, se agudiza face às dificuldades que tem o sistema capitalista de propiciar a oferta de meios de consumo coletivo aos setores subalternizados da sociedade brasileira, ainda mais tendo em vista a incapacidade do Estado para intervir nessa complexa situação de modo mais efetivo. ${ }^{7}$

Tais elementos ensejam um contexto complexo para o desenvolvimento de movimentos sociais urbanos. Em boa medida, esses movimentos correspondem a "transformações recentes da sociedade industrial capitalista". ${ }^{8}$ Mais detalhadamente:

Em poucas décadas, as transformações econômicas, sociais, culturais, etc., ocorridas nas cidades, criam condições para a emergência de novas estruturas de poder, novas organizações e novos movimentos sociais e políticos. [...] A estrutura urbana passa a ser reconfigurada em função da expansão urbana e dos novos arranjos entre as classes sociais. ${ }^{9}$

Assim, os movimentos sociais urbanos movem-se em torno de uma série de questões, carências e reivindicações pertinentes à vida urbana como entendida pelos setores populares: habitação, meios de transporte público, educação, saúde, cultura e lazer, creches, saneamento, fornecimento de água, luz e gás etc.

A gama de fatores condicionantes inerentes a esse processo de modernização estava presente na sociedade brasileira de meados do século $X X$, com o crescimento significativo do movimento operário (vide a grande greve operária de 1953 em São Paulo, por exemplo) e dos movimentos de bairros após a Segunda Guerra Mundial, especialmente a partir dos anos 1950. O sistema político populista então dominante no país dava conta, em maior ou menor grau, dos processos econômicos, sociais e culturais. ${ }^{10}$

Em São Paulo - foco de várias pesquisas pioneiras a respeito dos movimentos sociais urbanos - houve um boom de iniciativas associativas a partir dos anos 1950, que em grande parte se vinculou aos parâmetros populistas do fazer político no Brasil de então. A carreira de Jânio Quadros tomava seu impulso inicial a partir das Associações de Amigos de Bairros e das Sociedades Amigos de Bairros (SABS) paulistanas. Várias SABs surgiram e se desenvolveram ligadas a projetos políticos de parlamentares (vereadores, deputados) populistas. As SABs constituíam, então, um elo entre as reivindicações populares urbanas e o poder público. O Estado buscava atender, por vários motivos, a algumas dessas reivindicações. $^{11}$

Com o golpe militar de 1964 , as SABs foram cooptadas pela política do regime autoritário. Seu papel reivindicatório e mobilizador diminuiu progressivamente em favor de

\footnotetext{
${ }^{7}$ JACOBI, op. cit., p. 151-2.

${ }^{8}$ DURHAM, op. cit., p. 25.

${ }^{9}$ GOHN, op. cit., p. 24-5.

${ }^{10}$ SINGER, op. cit., p. 87; JACOBI, op. cit., p. 147.

${ }^{11}$ Ibidem, p. 87-8; ibidem, p. 147-8.
} 
uma função associativa, entendida em termos basilares, passando a ser mediadas burocraticamente por políticos locais ligados ao partido oficial da ditadura. Isso resultou num processo de esvaziamento, já que as fontes de legitimidade das SABs não mais estavam ancoradas em possíveis mobilizações, mas na chancela dada pelo regime militar. ${ }^{12}$ Obviamente, processos semelhantes ocorriam desde os anos 1950 em favelas e bairros pobres no Rio de Janeiro, bem como nos demais grandes centros urbanos do país.

Mas como se pode caracterizar essa trajetória histórica, na qual surgem e se alastram movimentos sociais urbanos, e que parece ter fim com o golpe de 1964 ?

\title{
CONSTRUÇÃO INTELECTUAL DOS “VELHOS” MOVIMENTOS SOCIAIS URBANOS
}

A construção da noção de "novos" movimentos sociais urbanos, assim como no caso do "novo sindicalismo", supõe necessariamente a elaboração intelectual sobre "velhos" movimentos sociais urbanos. Tal elaboração se dá, muitas vezes, simultaneamente ao diagnóstico do que seria o "novo", de modo relacional.

Pedro Jacobi, entre outros autores, identificou a emergência do "novo", inclusive temporalmente:

\begin{abstract}
Em meados dos anos 1970 os movimentos reivindicatórios populares emergem e se multiplicam no cenário dos aglomerados urbanos. Um conjunto de novos problemas e de reivindicações sociais gera a formação e o desenvolvimento de uma ampla variedade de movimentos populares de base [...]. A emergência dos movimentos populares urbanos com um novo caráter [...] tem como eixo determinante das suas lutas o crescente processo de exclusão dos benefícios da urbanização. ${ }^{13}$
\end{abstract}

Tais movimentos novos estavam "determinando a formulação de novos padrões organizatórios e uma ruptura com as práticas populistas do passado". ${ }^{14}$ Quais são, então, as características desses movimentos sociais urbanos vinculados ao populismo, ao "velho", para alguns estudiosos do tema?

Paul Singer indicou que o movimento de bairros em São Paulo crescia nos anos 1950, com Jânio Quadros neles se apoiando para construir sua carreira política. Quando das campanhas eleitorais, vários comitês janistas se transformavam em SABs na periferia paulistana, de modo deliberado, em função dos planos políticos de Jânio: "Tratava-se, no fundo, de trocar as obras e os serviços, financiados pelo erário público, pelo voto dos beneficiários." Isso aponta a dependência, em relação ao Estado, dos setores populares envolvidos em maior ou menor grau na política dominante. Tal padrão de relacionamento político foi seguido e reproduzido no decorrer dos anos 1960. As SABs continuavam crescendo em quantidade, quase sempre ligadas a projetos políticos de parlamentares

\footnotetext{
12 JACOBI, op. cit., p. 147 e 149; SINGER, op. cit., p. 90-1; GOHN, op. cit., p. 156.

${ }^{13}$ JACOBI, op. cit., p. 150.

14 Ibidem, p. 151.
} 
paulistas. $^{15}$

Nesses termos, a apropriação das SABs pelo sistema e pela cultura política populista é clara. A expressão política das massas urbanas emergentes, por meio dos movimentos sociais urbanos, ficaria submetida a relações clientelísticas e paternalistas, com suas lideranças cooptadas pelo populismo. Tal análise é comum a vários autores: além de Singer, Ilse Scherer-Warren, Maria da Glória Gohn e Pedro Jacobi. ${ }^{16}$ Este último, por exemplo, afirmou que as associações de bairros e SABs "são estimuladas pelo esquema político do populismo, sustentado numa participação controlada das classes populares." ${ }^{17}$ Da mesma forma, Carlos Nelson Ferreira dos Santos: "A partir do Estado Novo, o paternalismo político urbano vai assumir a forma do populismo demagógico." ${ }^{18}$ Esse padrão de sociabilidade política seria alterado de modo decisivo apenas com o advento do regime militar, a partir de 1964.

Nesse sentido, Ilse Scherer-Warren trouxe uma síntese muito esclarecedora e rica, a respeito:

\begin{abstract}
A pausa em termos de organização da sociedade civil, que ocorreu imediatamente após 1964, de forma mais geral pode representar o marco de separação entre o que se denomina movimentos sociais tradicionais e o surgimento de novas formas de organização ou o novo caráter de algumas das antigas organizações populares, pois algumas destas organizações continuam presas a suas formas tradicionais de atuação (clientelísticas, assistenciais e autoritárias). Sem dúvida, esta separação entre o "tradicional" e o "novo" é uma construção que atende fins heurísticos. Os movimentos sociais concretos expressam de forma variada, e em maior ou menor grau, a continuidade ou descontinuidade em relação à cultura política tradicional. Todavia, a partir do período mencionado, juntamente com a proliferação dos movimentos sociais, muito dentre esses lutam contra as formas tradicionais de se fazer política neste país e propõem novas formas de ação política, ainda que às vezes com uma dificuldade inicial em ultrapassar o nível do discurso. ${ }^{19}$
\end{abstract}

A identificação de "velhos" movimentos sociais urbanos - do pré-64 - com o populismo e com suas propriedades intrínsecas - clientelismo, paternalismo, assistencialismo, autoritarismo, cooptação das lideranças populares, participação controlada das camadas populares na política, dependência do Estado - é comum a vários autores, que, contudo, também registram nuances nessa caracterização.

Singer indicou que a conjuntura política dos anos 1950, com a emergência dos movimentos sociais urbanos "velhos" e a mobilização operária representada pela grande greve paulista de 1953, mostrava um despertar político de grandes camadas da população

\footnotetext{
${ }^{15}$ SINGER, op. cit., p. 87-8; JACOBI, op. cit., p. 147-8.

${ }^{16}$ SCHERER-WARREN, Ilse. O Caráter dos Novos Movimentos Sociais. In: SCHERER-WARREN, Ilse; KRISCHKE, Paulo J. (orgs.). Uma Revolução no Cotidiano? Os Novos Movimentos Sociais na América do Sul. 1. ed. São Paulo: Brasiliense, 1987, p. 35-53 (p. 42); GOHN, op. cit., p. 28 e 155; JACOBI, op. cit., p. 147.

${ }^{17}$ JACOBI, op. cit., p. 147-8.

18 SANTOS, Carlos Nelson Ferreira dos. Três Movimentos Sociais Urbanos no Rio de Janeiro. Dissertação (Mestrado). PPGAS/Museu Nacional/UFRJ, Rio de Janeiro, 1978, 416 p. (p. 399).

${ }^{19}$ SCHERER-WARREN, op. cit., p. 41.
} 
"que, até então, tinham-se deixado manipular, até certo ponto, por pelegos e políticos". ${ }^{20} \mathrm{Ou}$ seja, a subordinação dos "velhos" movimentos sociais urbanos ao populismo não era isenta de exceções e possibilidades de mudança.

Em direção similar, afirmou Gohn: "As SABs, apesar de peças importantes da engrenagem política existente, se constituíam num autêntico movimento social, pois desenvolviam junto à população políticas que as inseriam num contexto de participação.". ${ }^{21}$

Jacobi registrou que as SABs paulistas pré-64 não incluíam apenas a manipulação demagógica, mas desenvolviam uma função reivindicatória e mobilizadora, fornecendo um papel às classes populares no meio urbano e fazendo com que o Estado passasse a dar alguma atenção às necessidades imediatas da população da periferia. A respeito da presença dessas classes populares no cenário político, Jacobi cita José Álvaro Moisés, um dos principais estimuladores do debate a respeito dos movimentos sociais urbanos. ${ }^{22}$

Já Carlos Nelson Ferreira dos Santos, estudando os movimentos sociais urbanos em favelas e bairros cariocas ainda no duro período de repressão da ditadura militar, mencionou a experiência de luta em Brás de Pina nos anos 1967/68. ${ }^{23}$ Nela, os moradores se organizaram e resistiram às costumeiras remoções de populações carentes impostas pelas autoridades, a ponto de a questão ter grande repercussão na sociedade. A resposta do Estado, poucos anos depois abolida, consistiu na implementação de um projeto de urbanização local que ouvia e levava em conta as necessidades e desejos dos moradores, no plano habitacional e da infraestrutura urbana. Arquiteto/urbanista e antropólogo, Carlos Nelson Ferreira dos Santos foi um dos principais formuladores e gestores desse projeto de urbanização da favela de Brás de Pina, implementado de 1966 a 1969. Portanto, escreveu sobre tal experiência como ator envolvido e como observador etnográfico.

Depois das lutas urbanas em Brás de Pina, a FAFEG (Federação das Associações de Favelas do Estado da Guanabara) estimulou movimentos similares em outros bairros do Rio de Janeiro, mas o resultado acabou por ser diferente, com prisão das lideranças populares e repressão geral ao movimento. A FAFEG foi então progressivamente inviabilizada, num processo iniciado em 1968. O regime militar não tolerava movimentos sociais urbanos com posições políticas claras:

Com o advento e apogeu da FAFEG há uma tentativa de transformar movimentos eventuais em uma linha de ação contínua com objetivos próprios veiculados, enfim, a partir das bases. Isto vai durar pouco: em 1969 a FAFEG é submetida a uma repressão tal que fica esmagada. Só agora as idéias que defendia voltam a circular. $^{24}$

Essa passagem de Carlos Nelson Ferreira dos Santos é extremamente reveladora,

\footnotetext{
${ }^{20}$ SINGER, op. cit., p. 87.

${ }^{21} \mathrm{GOHN}$, op. cit., p. 156.

22 JACOBI, op. cit., p. 147-9. O trabalho de José Álvaro Moisés é Contradições Urbanas, Estado e Movimentos Sociais. Revista de Cultura e Política. São Paulo: n. 1, vol. 1, 1979.

${ }^{23}$ SANTOS, op. cit., p. 377. Os outros movimentos estudados por ele foram os do Morro Azul e do Catumbi.

${ }^{24}$ SANTOS, op. cit., p. 399 (nota); também, p. 379-80.
} 
justamente pela ligação temporal que estabeleceu entre uma tentativa "nova" de se fazer movimento social urbano, ainda no final dos anos 1960, seu fracasso e o fato de tais "novas" "ideias" voltarem "a circular" nos anos em que escrevia sua dissertação de mestrado, na segunda metade da década de 1970. Ele antevia na mobilização ocorrida em Brás de Pina elementos novos em termos de movimentos sociais urbanos - tão inovadores que, posteriormente, houve uma política sistemática de repressão às organizações da população de favelas no Rio de Janeiro por parte do regime militar. Apesar disso, aqueles elementos novos permaneceram latentes na realidade da sociedade civil brasileira durante quase dez anos, ressurgindo na década de 1970.

Nesse sentido, Brás de Pina está para a transição entre "velhos" e "novos" movimentos sociais urbanos como Contagem e Osasco estão para a transição do "velho" para o "novo sindicalismo". Em termos das mudanças do pensamento social e das ciências sociais no Brasil, a Brás de Pina de Carlos Nelson Ferreira dos Santos corresponde à visão weffortiana dos acontecimentos sindicais em Contagem e Osasco. ${ }^{25}$ Nestas duas cidades, porém, a repressão ao movimento foi imediata e concentrada nos sindicatos locais. Nos dois casos (Brás de Pina, por um lado, Contagem e Osasco, por outro), ensaiava-se o "novo" no movimento popular. Alguns intelectuais brasileiros detectaram agilmente essa "movimentação" da realidade. E, assim, o modelo de "novos" movimentos sociais, fosse no plano sindical, fosse no plano urbano, começava a ser esboçado. Possibilidades de mudanças na sociedade civil brasileira eram percebidas ou imaginadas.

A distância temporal entre o trabalho de Francisco Weffort sobre Contagem e Osasco, datado de 1972, e o trabalho de Carlos Nelson Ferreira dos Santos sobre Brás de Pina e mais dois movimentos urbanos do Rio de Janeiro (1978) é quase correspondente, pode-se dizer, à tradicional precedência que os estudos sindicais tiveram sobre as investigações de movimentos sociais urbanos no Brasil e no mundo, do ponto de vista da trajetória histórica. Ademais, o campo de estudos sindicais no Brasil, já então institucionalizado em nosso ambiente universitário, existia ao menos desde o início dos anos 1960, enquanto o campo de pesquisas sobre movimentos sociais urbanos começou a se desenvolver nas universidades apenas cerca de dez anos depois.

Por outro lado, o trabalho de Santos aparentemente não teve maior repercussão no campo intelectual brasileiro centrado nas ciências sociais, embora até hoje seja lembrado no campo de estudos urbanísticos. Já o trabalho de Weffort cedo tornou-se paradigmático no campo dos estudos sindicais. Por fim, Weffort apostava no que Contagem e Osasco traziam de novo para o movimento sindical - no que acertou em grande medida. E Santos era bastante cético a respeito da experiência de Brás de Pina poder ser reproduzida de modo bem-sucedido em outros locais e em outros momentos históricos.

De qualquer forma, o "novo" antevisto por Carlos Nelson Ferreira dos Santos e por outros estudiosos será proclamado pela maioria dos autores dedicados à pesquisa dos movimentos sociais urbanos nos anos 1970/80, como veremos a seguir.

\footnotetext{
${ }^{25}$ Trata-se do clássico estudo WEFFORT, Francisco. Participação e Conflito Industrial: Contagem e Osasco 1968. Estudos CEBRAP, São Paulo, n. 5, 1972.
} 


\section{CARACTERÍSTICAS DOS “NOVOS” MOVIMENTOS SOCIAIS URBANOS}

Paul Singer, descrevendo genericamente a emergência de movimentos sociais urbanos nos anos 1970, apontou a solidariedade mútua como o tipo de atividade capaz de suprir inicialmente as carências urbanas dos moradores de bairros operários e populares. Posteriormente, eles passariam à "organização para reivindicar benfeitorias e serviços, que não podem ser alcançados pela ação própria dos moradores, mas dependem da ação do Estado". ${ }^{26}$ E diagnosticou:

É da interação destes dois tipos de atividade - para dentro e para fora - que surgem as contradições de classe no seio do próprio movimento de bairro, que levam à crise da sua primeira forma de organização - a SAB - e a sua superação, mediante a criação de novas modalidades de organização [...]. ${ }^{27}$

Singer prosseguiu:

O que caracteriza o novo movimento de bairro, em São Paulo, em contraste com o antigo (das $S A B s$ ), é que ele surge a partir de uma proposta para dentro: criar uma nova consciência, uma mentalidade de união para a auto-ajuda na população. A ação para fora decorre desta atitude e as reivindicações levantadas assume o caráter de exigência de direitos e não de dádivas a serem obtidas mediante barganha com os representantes do Estado. ${ }^{28}$

E afirmando sobre os movimentos sociais urbanos articulados em torno da questão habitacional, concluiu: "A novidade está no fato de que estes pobres e humildes estão conseguindo se unir para a defesa de seus direitos." ${ }^{29}$

A proclamação do "novo" transparecia inclusive em subtítulos dos trabalhos então realizados, tais como $O$ novo movimento de bairro em São Paulo e Características $e$ perspectivas do novo movimento de bairro; ou $A$ nova organização do povo: a luta pela conquista de creches e centros de saúde. ${ }^{30}$ Pedro Jacobi indicou que "a prática do clientelismo e da troca de favores - por sinal, práticas dominantes - não mais têm espaço no quotidiano dessa nova organização da população da periferia". Esta camada da população estava "delineando novas formas de ação", tais como "os movimentos por creches e centros de saúde [que] representam assim um dado novo nas lutas populares". ${ }^{31}$ Maria da Glória Gohn percebeu uma "uma nova forma de conflito", que constituía "uma nova realidade". As SABs paulistanas nos anos 1970 já apontavam para "formas novas de participação social". ${ }^{32}$ Ilse Scherer-Warren, conforme já visto, também chamou a atenção para o caráter novo dos

\footnotetext{
${ }^{26}$ SINGER, op. cit., p. 89.

27 Ibidem, p. 89.

${ }^{28}$ Ibidem, p. 105 (grifos no original).

${ }^{29}$ SINGER, op. cit., p. 94.

30 Ibidem, p. 93 e 104 (as duas primeiras citações, respectivamente); JACOBI, op. cit., p. 151 (a última citação).

${ }^{31} \mathrm{JACOBI}$ op. cit., p. 179 e 152, respectivamente.

${ }^{32} \mathrm{GOHN}$, op. cit., p. 13, 26 e 156, respectivamente.
} 
movimentos sociais emergentes nos anos $1970 .^{33}$ E prognosticou: "Os novos movimentos sociais não apresentam projetos bem definidos para o futuro, mas parece-me que estão construindo as bases para uma vida mais democrática e mais socializada.." ${ }^{34}$ E mais: "[...] a meu ver, estes movimentos estão construindo e desenvolvendo uma nova cultura política de base." ${ }^{35}$

José Álvaro Moisés e Verena Martinez-Alier, pesquisando os quebra-quebras promovidos espontaneamente por pessoas nos subúrbios de São Paulo e Rio de Janeiro, indicou esse potencial de novidade da seguinte forma: "[...] algo de novo estava ocorrendo entre as massas populares urbanas que, agora, ofereciam uma reação qualitativamente nova diante de suas difíceis condições de existência material." ${ }^{36}$

Fazendo menção tanto ao espaço político sindical quanto ao espaço político dos movimentos sociais urbanos, Vera da Silva Telles afirmou:

\begin{abstract}
A derrota de 1964, a repressão e o fechamento do espaço sindical, o "exílio nas fábricas" e os acontecimentos de 1968 são evidências de um tempo histórico que desestruturava os espaços tradicionais por onde se fazia a experiência da sociedade e da política. Um tempo, sobretudo, que desmontava as condições de eficácia das referências instituídas do pensamento e da ação política. Daí que a "introjeção no mundo cotidiano", enfatizada por tantos que trataram do período, pode ser pensada como algo mais que um resultado objetivo das condições impostas pelo autoritarismo. É possível dizer que significava uma experiência tão nova em relação às tradições políticas conhecidas que passava a exigir novos códigos e novas palavras para tornar possível pensar o presente e reabrir o futuro, enquanto horizonte de ação. ${ }^{37}$
\end{abstract}

Telles chegou a falar sobre a "construção de espaços sociais e políticos, a partir de práticas instituintes de novas realidades e novos significados". ${ }^{38}$ Ruth Cardoso mostrou-se mais reticente quanto às possibilidades do "novo", ainda que observando seu potencial político:

Os movimentos de bairro, quando vistos por sua face reivindicativa, não parecem capazes de grandes transformações, mas quando os vemos como expressão de uma nova identidade, é possível pensar que venham a ser uma nova peça no jogo político. $^{39}$

Com todas essas assertivas de diversos estudiosos, o "novo" presente nos movimentos sociais urbanos parece assumir diversas formas, dimensões e significados. Nesse encadeamento de registros, pode-se concluir com Eunice Durham que esses

\footnotetext{
${ }^{33}$ SCHERER-WARREN, op. cit., p. 41-2.

34 Ibidem, p. 50.

35 Ibidem, p. 36.

${ }^{36}$ MOISÉS e MARTINEZ-ALIER, op. cit., p. 17.

37 TELLES, Vera da Silva. Anos 70: Experiências, Práticas e Espaços Políticos. In: KOWARICK, Lúcio (org.). As Lutas Sociais e a Cidade: São Paulo Passado e Presente. 1. ed. São Paulo: Paz e Terra/CEDEC/UNRISD, 1988, p. 247-86 (p. 256-7).

${ }^{38}$ Ibidem, p. 257 (grifos no original).

${ }^{39}$ CARDOSO, op. cit., p. 238.
} 
emergentes movimentos sociais urbanos remetiam a "uma nova prática coletiva, que passa a fazer parte integrante da vida social e fundamenta novas representações". Mais ainda: "parece que estamos vivendo um processo de construção coletiva de uma nova cidadania". Por fim, consistiam num "revelador sinal dos novos tempos". ${ }^{40}$

Mas quais são os atributos dos "novos" movimentos sociais urbanos, indicados por intelectuais brasileiros estudiosos do assunto e atuantes nos anos 1970/80? A partir da análise de nove trabalhos de dez autores - Ruth Cardoso, Eunice Durham, Pedro Jacobi, Carlos Nelson Ferreira dos Santos, Paul Singer, Maria da Glória Gohn, Ilse Scherer-Warren, Vera da Silva Telles, José Álvaro Moisés e Verena Martinez-Alier ${ }^{41}$ - elaborei o seguinte apanhado de características relacionadas aos chamados "novos" movimentos sociais urbanos no Brasil que retomava o caminho da democracia ${ }^{42}$ :

i. Defensores da ação direta, muitas vezes contrariando as leis vigentes, e de práticas autogestionárias (Cardoso, 1983, p. 231; Gohn, 1982, p. 16; Jacobi, 1983, p. 154, 159, 170, 174/176 e 178/179; Moisés e Martinez-Alier, 1978, p. 29/31, 34/35, 40/41, 54 e 56; Santos, p. 340/341; Scherer-Warren, 1987, p. 42 e 50; Singer, 1980, p. 94 e 105/107).

ii. Demandantes junto às diversas autoridades do Estado ou, em menor grau, junto a setores empresariais ${ }^{43}$, usando meios legais, inclusive judiciais, ou também buscando chamar a atenção da grande imprensa (Cardoso, 1983, p. 226, 228, 230/231 e 233/234; Gohn, 1982, p. 12/13, 16 e 30/31; Jacobi, 1983, p. 149/150, 154, 155, 159/161, 163, 165/166, 168, 171 e 173; Santos, 1978, p. 332, 335 e 340; Singer, 1980, p. 89, 91, 94, 102/104 e 105; Telles, 1988, p. 270).

iii. Reivindicativos em diversas questões (habitação, transportes públicos, saúde, creches, etc.), algumas dessas inovadoras no cenário político e popular (Cardoso, 1983, p. 233 e 234; Durham, 1984, p. 26/28; Gohn, 1982, p. 13, 16, 26 e 30; Jacobi, 1983, p. 151, 152, 155, 160, 162, 165 e 170/171; Moisés e Martinez-Alier, 1978, p. 20 e 51; Santos, 1978, p. 340; Scherer-Warren, 1987, p. 48; Singer, 1980, p. 83, 89, 94 e 102/104; Telles, 1988, p. 262, 265 e 270).

iv. Críticos em relação a movimentos e entidades tradicionais de moradores: ignorando-as ou disputando suas direções contra lideranças mais antigas (por vezes oriundas de esquemas populistas) ou ligadas ao regime militar (Gohn, 1982, p. 155/157 e 165; Jacobi, 1983 , p. 147/151 e 178; Santos, 1978, p. 399; Scherer-Warren, 1987, p. 42 ; Singer, 1980, p. 89/93 e 105).

v. Autônomos, muitas vezes antiestatais e anti-institucionais, normalmente no sentido de um difuso, mas firme repúdio à política institucional em geral, corporificada nas

\footnotetext{
${ }^{40}$ DURHAM, op. cit., p. 28, 29 e 30, respectivamente.

${ }^{41}$ Todos os trabalhos dos autores em questão foram citados em notas anteriores. Os textos escolhidos (escritos num intervalo de mais de 10 anos) abarcam autores diversos - em termos de orientações teóricas e ideológicas, trajetória profissional, origem institucional, experiência política etc.

42 Optei aqui por citar os autores em cada item correspondente a uma característica dos "novos" movimentos sociais urbanos, utilizando o padrão norte-americano, a fim de evitar um número muito grande de notas de pé de página, o que, inevitavelmente, ocorreria.

${ }^{43}$ Por exemplo, junto a empresas imobiliárias responsáveis pela mercantilização de terrenos - de modo ilegal ou não - ocupados por pessoas carentes em termos de moradia.
} 
diversas instâncias do Estado e órgãos públicos - Poderes Executivos federal, estadual e municipal, parlamentos, esferas do Poder Judiciário etc. (Cardoso, 1983, p. 226, 228, 230, 231/232; Durham, 1984, p. 27, 29 e 30; Gohn, 1982, p. 32/33, 161 e 165; Jacobi, 1983, p. 154, 159, 162, 173, 178 e 179; Moisés e Martinez-Alier, 1978, p. 19, 29 e 56; Scherer-Warren, 1987, p. 42 e 50; Singer, 1980, p. 105/107; Telles, p. 1988, p. 250, 263, 270 e 276/278).

vi. Comunitaristas - no sentido genérico da construção de uma identidade local dos moradores pobres enquanto comunidade distinta da sociedade em geral - e igualitaristas (Cardoso, 1983, p. 231/234; Durham, 1984, p. 27/28 e 30; Gohn, 1982, p. 10 e 12; Jacobi, 1983, p. 149/150 e 178; Moisés e Martinez-Alier, 1978, p. 41; Santos, 1978, p. 329/331 e 362/363; Scherer-Warren, 1987, p. 42 e 50; Singer, 1980, p. 83, 89, 91/92 e 105; Telles, p. 1988, p. 262, 265 e 266).

vii. Interclassistas, articulando uma base social heterogênea em termos de ocupação, mas compostos normalmente por pessoas pobres e/ou das periferias das grandes cidades (alguns, migrantes de origem rural), contando algumas vezes com a presença de setores das classes médias (Durham, 1984, p. 24 e 26; Gohn, 1982, p. 12, 28 e 157; SchererWarren, 1987, p. 39; Singer, 1980, p. 89/90).

viii. Firmes e meticulosos na organização dos processos de luta: reivindicando e acompanhando as questões envolvidas, algumas vezes lançando mão de conhecimentos elaborados no universo popular, outras vezes contando com a assessoria de profissionais engajados e com conhecimentos especializados - advogados, assistentes sociais, arquitetos e urbanistas etc. (Cardoso, 1983, p. 226, 228 e 230/231; Jacobi, 1983, p. 165/166 e 173/175; Moisés e Martinez-Alier, 1978, p. 34/35; Santos, 1978, p. 328/329, 341, 365 e 367/368; Singer, 1980, p. 83, 94, 102/104 e 105/106).

ix. Espontâneos, desenvolvendo lutas a partir de iniciativas voluntárias diversas, muitas vezes sem maior organização (Durham, 1984, p. 26; Gohn, 1982, p. 12; Moisés e Martinez-Alier, 1978, p. 20, 22, 29/32, 34, 41/43, 51, 54 e 56; Santos, 1978, p. 340).

x. Ciosos da importância do trabalho de base e da democracia interna, massivos e dotados de múltiplas formas de articulação, tendo como resultado a formação de uma nova geração de militantes populares, especialmente nos setores periféricos das grandes cidades (Durham, 1984, p. 27/28; Gohn, 1982, p. 12/13, 26, 32/33 e 157; Jacobi, 1983, p. 149/150, 161, 166, 170/172 e 178; Moisés e Martinez-Alier, 1978, p. 30/32 e 41; SchererWarren, 1987, p. 36, 42 e 48; Singer, 1980, p. 93 e 107; Telles, 1988, p. 262/263 e 269/271).

xi. Valorizadores das experiências cotidianas e vivência subjetiva das questões e problemas pertinentes aos setores populares como fontes de reflexão, luta e autoconsciência da inserção individual e/ou coletiva de seus membros na sociedade (Cardoso, 1983, p. 232; Durham, 1984, p. 28 e 30; Santos, 1978, p. 337/338; Telles, 1988, p. 256/257, 262 e 269/270).

xii. Influenciados ideologicamente pelos diversos trabalhos pastorais (Pastoral da Periferia, Operária, da Juventude etc.) da Igreja Católica, via Teologia da Libertação, CEBs e outros grupos religiosos, bem como por grupos da esquerda marxista, especialmente os dissidentes da matriz pecebista, havendo ativistas tanto com quanto sem experiência prévia 
em movimentos populares (Cardoso, 1983, p. 230/231; Durham, 1984, p. 29; Gohn, 1982, p. 157; Jacobi, 1983, p. 149/150, 166 e 175; Santos, 1978, p. 366; Scherer-Warren, 1987, p. 42/43; Singer, 1980, p. 89, 91, 94 e 102/104; Telles, 1988, p. 262 e 269/271).

xiii. Criadores de um novo espaço público para o exercício da cidadania e a luta por direitos (Cardoso, 1983, p. 229, 231, 236 e 238; Durham, 1984, p. 28/29; Gohn, 1982, p. 9/10, 12 e 24/25; Jacobi, 1983, p. 147/151, 173, 175 e 178/179; Moisés e Martinez-Alier, 1978, p. 17, 32 e 56; Scherer-Warren, 1987, p. 36, 41, 42, 48 e 50; Singer, 1980, p. 91, 92, 93, 104 e 106/107; Telles, p. 1988, p. 250, 256/257, 267/271 e 277).

Num primeiro olhar, é possível caracterizar os novos movimentos sociais urbanos predominantemente como: pró-ação direta (item i); demandantes do Estado (item ii); diversificadamente reivindicacionistas (iii); críticos de entidades tradicionais de moradores (iv); autonomistas/antiestatais/anti-institucionais (v); comunitaristas/igualitaristas (vi); bem organizados (viii); valorizadores do trabalho de base e da democracia interna (x); e, por fim, criadores de um novo espaço público para o exercício da cidadania e a luta por direitos (item xiii). Entre as propriedades menos apontadas pelos autores como características dos novos movimentos sociais urbanos, pode-se destacar: interclassistas (item vii); valorizadores da espontaneidade (ix) e das experiências cotidianas; ou que envolvem a subjetividade de seus participantes (xi).

A valorização da espontaneidade, do cotidiano e da subjetividade dos atores envolvidos nos movimentos sociais urbanos possui muitos nexos, a meu ver, com as demais características majoritariamente elencadas pelos autores em questão. Suponho que essa múltipla valorização não apareça de modo expressivo em meu conjunto de textos, possivelmente pelo fato de serem tais temas ainda recentes no pensamento social e nas ciências sociais brasileiras do período. Estando correta essa hipótese, a espontaneidade, o cotidiano e a subjetividade apareceriam como novidades no debate intelectual, que viriam a ser analisadas com mais consistência apenas depois dos anos 1970/80.

\section{MOVIMENTOS SOCIAIS URBANOS E PENSAMENTO SOCIAL BRASILEIRO: DIVERSAS INTERPRETAÇÕES}

Se os "novos" movimentos sociais urbanos são definidos principalmente em termos de "novas" formas de empreender articulações políticas no plano da sociedade civil, em contraposição às "velhas" formas, torna-se menos relevante a afirmação de Paul Singer, no sentido de que os movimentos urbanos são mais importantes nas cidades dos países subdesenvolvidos, que contam com rápido crescimento urbano e consequentes condições precárias de vida. ${ }^{44} \mathrm{O}$ mesmo poderia ser dito em relação ao diagnóstico de Maria da Glória Gohn, de que no capitalismo clássico, as contradições urbanas são secundárias, enquanto no Brasil e formações sociais similares, tais contradições são tão importantes quanto a existente entre capital e trabalho. ${ }^{45}$

\footnotetext{
${ }^{44}$ SINGER, op. cit., p. 85.

${ }^{45} \mathrm{GOHN}$, op. cit., p. 30.
} 
Os aspectos estruturais, econômicos e espaciais apontados acima por Singer e Gohn podem ser considerados, no máximo, como mediadores específicos daquele modo "novo" de se fazer movimentos sociais, definido por Scherer-Warren. Definição que, por si só, remete a uma realidade mais ampla e a uma dissensão cultural, ideológica e político-social que não se prendem a situações particulares de dependência econômico-social ou à dicotomia desenvolvimento-subdesenvolvimento, mas à modernidade e à contemporaneidade como um todo.

Ruth Cardoso construiu um contexto esclarecedor a respeito. Ela afirmou que as discussões sobre marginalidade e dependência, enfatizando as especificidades do desenvolvimento latino-americano, criaram um novo quadro teórico para a análise da industrialização periférica. Nesse quadro, a questão da marginalidade social colocava os excluídos do sistema capitalista como capazes de transformar a sociedade, algo que, no entender da autora, acabou não acontecendo. Além disso, ela mostrou que os movimentos sociais brasileiros eram semelhantes aos registrados nos países desenvolvidos e industrializados. ${ }^{46}$

É importante relembrar, contudo, que a síntese de Scherer-Warren relativa ao "novo" nos movimentos sociais, efetuada em meados dos anos 1980, é um pouco posterior às citadas análises de Singer e Gohn, feitas na transição dos anos 1970 para os 80 . A pequena diferença temporal-conjuntural dos trabalhos em questão é significativa. De modo geral, no intervalo de tempo entre 1970 e 1990, os referenciais teóricos utilizados nas investigações sobre movimentos sociais urbanos - bem como sobre o movimento sindical - foram se afastando progressivamente de parâmetros econômicos e estruturais. Sem deles abrir mão totalmente, caminham em direção a uma dimensão predominantemente sociocultural.

É certo que Gohn e Singer estavam chamando a atenção para elementos históricoconjunturais que incidiam efetivamente na emergência e no desenvolvimento dos movimentos sociais urbanos no Brasil a partir dos anos 1970. Gohn ressaltava que o país passava por uma crise de hegemonia política desde 1975, na qual aumentavam as pressões por participação e representação política, que atingiam inclusive as velhas SABs, muitas delas sofrendo significativas alterações. ${ }^{47} \mathrm{~A}$ autora também apontou as diferenças entre os movimentos sociais urbanos europeus e seus similares latino-americanos, já que envolviam processos históricos, políticos e culturais distintos: “A mera transposição de 'modelos' de análise constituiria uma simplificação distorcedora da realidade; as análises dos cientistas europeus, sobre movimentos sociais urbanos, devem constituir apenas marcos de referência." $^{48}$

As particularidades históricas de cada sociedade, enquanto contexto explicativo para a emergência de "novos" movimentos sociais urbanos, encontram uma forma muito clara na argumentação de Moisés e Martinez-Alier sobre a relação entre tais movimentos e as ditaduras militares como a brasileira. Em seu trabalho já citado, a dupla de autores

\footnotetext{
${ }^{46}$ CARDOSO, op. cit., p. 215 e 229.

${ }^{47}$ GOHN, op. cit., p. 164.

${ }^{48}$ Ibidem, p. 17.
} 
afirmou:

Na ausência completa de canais institucionais próprios de reivindicação, a única maneira de se fazer ouvir é a ação direta, dirigida contra aquilo que está ao alcance imediato: os próprios trens e as estações onde os trabalhadores vivem parte de seu drama diário. 49

Gohn expôs o mesmo tipo de reflexão ao indicar que, estando os canais de expressão popular e de classe tradicionais - partidos e sindicatos - suprimidos pelo regime militar, "determinados canais criados a partir da própria população tendem a assumir importância muito além de suas dimensões". Estes canais seriam os de base local, principalmente os movimentos sociais urbanos. ${ }^{50}$

Nas passagens acima, fica claro que o surgimento de movimentos sociais urbanos baseados na ação direta ou localmente - o que certamente configurava uma novidade em termos da história das articulações da sociedade civil no Brasil - era motivado pela ausência de democracia representativa. Essa tese foi extensamente adotada no campo intelectual bem como no campo dos movimentos populares - do Brasil no período.

Ruth Cardoso e Eunice Durham relativizaram essa imagem do desencadeamento de movimentos sociais urbanos por conta de contextos autoritários. Ambas lembraram que os movimentos sociais brasileiros do período pós-64 eram semelhantes a movimentos contemporâneos de sociedades com democracia representativa, inclusive na América Latina. Outra evidência a respeito residia no fato, apontado por Durham, de que a abertura democrática, permitindo a retomada da vida político-institucional e partidária, não diminuíra o ímpeto expansivo dos movimentos sociais urbanos, bem como do movimento sindical. 0 que, no mínimo, problematiza a argumentação de Moisés e Martinez-Alier de que os canais institucionais suprimidos no regime militar brasileiro teriam favorecido a ação direta dos setores populares. ${ }^{51}$ Cardoso e Durham mostravam que os movimentos sociais urbanos não se confundiam com a democracia representativa. Assim, os "novos" movimentos sociais urbanos não emergiram no Brasil dos anos 1970 para substituir os partidos como veículos de expressão das vontades populares e da cidadania. Durham foi peremptória ao apontar que os movimentos sociais em geral não são substitutos eventuais da atuação partidária e sindical, nem formas inferiores em relação a esses tipos de atuação política. ${ }^{52} \mathrm{~A}$ tese "substitucionista", esposada - temporariamente ou não - por Moisés e Martinez-Alier, Gohn e outros autores não explica decisivamente a novidade dos movimentos sociais urbanos.

Portanto, a especificidade ou singularidade das situações de subdesenvolvimento, dependência ou autoritarismo não fornece elementos que contextualizem ou expliquem, de maneira central, o porquê do surgimento desse "novo" modo de se construir movimentos sociais urbanos no Brasil a partir dos anos 1970.

Do ponto de vista das mudanças pelas quais passava o campo intelectual brasileiro

\footnotetext{
${ }^{49}$ MOISÉS e MARTINEZ-ALIER, op. cit., p. 29.

${ }^{50} \mathrm{GOHN}$, op. cit., p. 30-1.

${ }^{51}$ CARDOSO, op. cit., p. 229; DURHAM, op. cit., p. 25.

52 DURHAM, op. cit., p. 25.
} 
voltado para o estudo dos atores sociais nacionais no período, que significados tem a afirmação do parágrafo imediatamente acima? A mais antiga discussão em torno do subdesenvolvimento e o debate posterior sobre a dependência remetem a dimensões muito abrangentes e estruturais, além de "externas" aos movimentos sociais em geral, aí incluídos os urbanos. Além disso, mesmo a teoria da dependência estava longe de ser sofisticada no que tange ao tratamento dos atores sociais brasileiros, estando grandemente relacionada à dimensão econômica, alcançando, no máximo, um escopo socioeconômico.

Já a questão do autoritarismo político brasileiro, que abarca as discussões em torno da ditadura militar iniciada em 1964, também é estrutural, mas no plano dos modelos políticos. Pensando tais modelos ainda centrados na política institucional, está-se ainda num campo "externo" ao dos movimentos sociais, mesmo que mais próximo deles por tratar de aspectos político-sociais da realidade brasileira, mais do que da dimensão socioeconômica.

Os temas da dependência e do autoritarismo político, contudo, eram dotados de pouca flexibilidade para dar conta de uma compreensão rica e matizada das articulações da sociedade civil brasileira do período, especialmente de seus movimentos sociais. A caminhada que nossas ciências sociais faziam rumo a uma apreensão empírica cada vez mais densa e detalhada, constituindo mesmo uma inflexão fenomenológica, exigia uma diversidade de olhares para os movimentos populares, para seus conteúdos e significados mais próprios. Ressalte-se, ainda, que a tese "substitucionista" nem sempre foi levantada pelos estudiosos dos movimentos sociais como algo essencial, muito menos foi capaz de turvar a capacidade de análise quanto às características e potencialidades dos movimentos sociais urbanos no Brasil pós-64.

Isso é demonstrado pela passagem abaixo, de Moisés e Martinez-Alier:

\begin{abstract}
Desta forma, esses movimentos sociais das massas suburbanas, baseados na ação direta, colocam uma série de problemas novos para a avaliação do papel político das classes populares na sociedade. Estamos diante de movimentos sociais que têm como ponto de partida a ação espontânea e não-organizada [...]; porém, ao contrário dos movimentos pré-políticos, ocorrem no contexto de uma sociedade industrial. Seria simples demais desclassificá-los como meros resíduos de uma etapa histórica anterior. Trata-se, no caso, de encontrar as suas raízes na própria natureza do modelo político brasileiro atual e de apreender a sua especificidade dentro dele. ${ }^{53}$
\end{abstract}

A partir desse trecho, pode-se visualizar que é possível inserir os movimentos sociais urbanos, sem condicionantes analíticos rígidos ou empobrecedores, na especificidade da sociedade e da política brasileiras.

Um aporte teórico-analítico muito utilizado nos primeiros trabalhos sobre movimentos sociais urbanos no Brasil foi o centrado nas chamadas contradições urbanas. Tal aporte foi usado nas ciências sociais brasileiras por especialistas nesse campo interdisciplinar do conhecimento nos anos 1970, a partir de leituras do marxismo aplicadas à dimensão urbana. Alguns autores pioneiros do campo foram Castells, Borja, Lefebvre e Lojkine.

\footnotetext{
${ }^{53}$ MOISÉS e MARTINEZ-ALIER, op. cit., p. 54.
} 
Pesquisas sobre movimentos sociais urbanos enquanto desdobramentos das lutas de classes realizadas nessa linha na França e Espanha eram inspirações para os estudiosos brasileiros de então. ${ }^{54}$ Muitos dos que começavam a ter destaque no campo intelectual brasileiro pesquisaram nessa perspectiva, como Maria da Glória Gohn, José Álvaro Moisés e Verena Martinez-Alier, entre outros. ${ }^{55}$

O trabalho realizado em dupla por Moisés e Martinez-Alier foi muito influente nas ciências sociais e no pensamento social brasileiro voltado para os movimentos urbanos, se equiparando, como referência analítica, aos citados autores estrangeiros. ${ }^{56}$ Luiz Antonio Machado da Silva e Ana Clara Torres Ribeiro apontaram outros trabalhos de Moisés como paradigmáticos para os novos estudos sobre movimentos sociais urbanos, ${ }^{57}$ bem como o fato de ele ter sido influenciado pelas análises de Francisco Weffort. ${ }^{58}$

As discussões baseadas nas contradições urbanas são descendentes da curta - mas expressiva - predominância do estruturalismo althusseriano no marxismo europeu, que foi também bastante influente no campo intelectual e no pensamento social brasileiros da transição dos anos 1960 para 1970. Seu veio estrutural aparece em vários trabalhos sobre movimentos sociais urbanos, o que não deixa de ser curioso, visto que estes trilhavam cada vez mais perspectivas empiristas ou fenomenológicas, pouco afeitas a teorias mais abrangentes ou enfoques de maior alcance.

Não é à toa que o paradigma das contradições urbanas foi um dos primeiros a ser adotado entre os estudiosos brasileiros dos movimentos sociais urbanos, sendo depois rediscutido, flexibilizado e criticado a partir de exigências empíricas mais rigorosas e parâmetros fenomenológicos voltados para os atores sociais, normalmente pouco privilegiados analiticamente em enfoques estruturalistas. Talvez o fato de o campo de estudos dos movimentos sociais urbanos estar se iniciando no Brasil, ao contrário do já existente campo de estudos sindicais, tenha facilitado a adoção de um corpo teórico internacionalmente em voga, notadamente em universidades europeias.

No marxismo, as contradições urbanas remetem diretamente à noção mais ampla de contradição entre capital e trabalho, entre burguesia e proletariado. Elas constituiriam outra dimensão contraditória das sociedades capitalistas. Gerando efeitos na estrutura de classe, as contradições urbanas apontam para o desenvolvimento de ações coletivas urbanas, que, por sua vez, geram efeitos na estrutura urbana. A questão urbana aí subjacente refletiria a crescente importância dos meios de consumo coletivos para o processo de acumulação do capital na fase monopolista do capitalismo. Por fim, para o provimento de tais meios de consumo, assume um papel novo e central o Estado, que, portanto, torna-se fator fundamental a ser levado em conta pelos movimentos sociais

\footnotetext{
${ }^{54}$ CARDOSO, op. cit., p. 216-7; GOHN, op. cit., p. 11; SANTOS, op. cit., p. 337.

${ }^{55}$ GOHN, op. cit., p. 13 e 17; MOISÉS e MARTINEZ-ALIER, op. cit., p. 45.

${ }^{56}$ Ver, por exemplo: SANTOS, op. cit., p. 337. E mais explicitamente: SILVA, Luiz Antonio Machado da; RIBEIRO, Ana Clara Torres. Paradigma e Movimento Social: Por Onde vão Nossas Idéias. Mimeo. São Paulo, ANPOCS, 1984 , p. 322.

${ }^{57}$ Entre os trabalhos citados de José Álvaro Moisés, destaco: Classes Populares e Protesto Urbano. Tese (Doutorado). USP, São Paulo, 1978.

${ }^{58}$ SILVA e RIBEIRO, op. cit., p. 322.
} 
urbanos e por seus estudiosos. ${ }^{59}$ Desse modo, como ressaltaram Moisés e Martinez-Alier, a questão urbana demandava "soluções globais, a serem tomadas a um nível social mais amplo, situadas ao nível das macrodecisões, só passíveis de serem tomadas pelo Estado." ${ }^{60}$ Nas próprias palavras dessa dupla de autores, essa questão urbana

\begin{abstract}
deriva das contradições geradas pelo desenvolvimento do capitalismo ante as novas e sempre crescentes necessidades postas para a reprodução da força de trabalho ou, por outras palavras, o consumo coletivo - e a política urbana de inversões privadas e públicas, que se dirigem aos setores mais rentáveis da produção e do consumo e que acabam por determinar a prioridade dos serviços destinados a expandir a produção sobre os serviços destinados a atender às necessidades de subsistência da população. ${ }^{61}$
\end{abstract}

Moisés e Martinez-Alier, chamaram a atenção, contudo, para o caráter dúplice da atuação estatal: por um lado, a intervenção econômica do Estado, por outro, sua função estratégica na manutenção política e ideológica do sistema e das relações de poder. Nos próprios termos dos autores:

[...] falar em reprodução das relações de produção implica considerar o papel do Estado nas sociedades capitalistas em sua dupla determinação [...]. Mas não se trata aqui, naturalmente, de cair em um mecanicismo de tipo economicista, que explicaria a política e a história (ou a superestrutura) como simples reflexo da estrutura econômica. 62

De qualquer modo, nesse aporte teórico-analítico, o urbano e seus movimentos sociais são entendidos enquanto "expressão social do processo de reprodução do capital e da força de trabalho" e "espaço de reprodução das classes sociais", como afirmava Maria da Glória Gohn. ${ }^{63}$ O viés analítico centrado nas "novas contradições urbanas" ${ }^{64}$ teve como resultado a configuração, para as sociedades contemporâneas, de uma "nova problemática urbana". ${ }^{65}$ A novidade dos correlatos movimentos sociais urbanos estudados no Brasil e no mundo, no período, já está, então, colocada.

Pesquisando na perspectiva das contradições urbanas, Gohn afirmou: "A postura crítica da não autonomia do urbano é de fundamental importância. Ele é determinado por outras instâncias da realidade [...] [é] parte de uma problemática totalizante". Por fim, asseverou: "os diferentes padrões de acumulação determinam diferentes urbanos, e os determinam por diferentes mediações, não diretamente." ${ }^{66}$

Desse modo, fica claro que os estudos dos movimentos sociais urbanos a partir da noção de contradições urbanas permite uma leitura que demarca fortemente os limites da

\footnotetext{
${ }^{59} \mathrm{GOHN}$, op. cit., p. 15 e 20; CARDOSO, op. cit., p. 218.

${ }^{60}$ MOISÉS e MARTINEZ-ALIER, op. cit., p. 47.

${ }^{61}$ Ibidem, p. 44-5 (grifos no original).

62 Ibidem, p. 45 (grifos no original).

${ }^{63} \mathrm{GOHN}$, op. cit., p. 20 (nota).

${ }^{64}$ CARDOSO, op. cit., p. 216-7.

${ }^{65} \mathrm{GOHN}$, op. cit., p. 20.

${ }^{66}$ Ibidem, p. 20 (nota).
} 
própria análise, pois esta se ancora na contradição principal da luta de classes: a que opõe burguesia/capital a proletariado/trabalho. A falta de autonomia do urbano e seus movimentos sociais refere-se a certa subordinação à dimensão estrutural da contradição maior do corpo teórico-analítico do marxismo. Melhor dizendo, às dimensões estruturantes dessa contradição, nas quais necessariamente tem de estar circunscrita a esfera dos movimentos sociais urbanos.

Tal conclusão estava muitas vezes apenas latente nas pesquisas e análises de alguns estudiosos dos novos movimentos sociais urbanos; outras vezes, estava bastante explícita, como na passagem abaixo de Gohn:

\begin{abstract}
Se num primeiro momento os movimentos urbanos objetivam a obtenção de melhorias imediatas, seu crescimento poderá levar a efeitos: quer no plano urbano, de obtenção das melhorias reivindicadas, quer no plano social, alterando a lógica das relações de classe existentes. Este último aspecto cremos que só será possível a partir da sua articulação com formações partidárias ou que perpassem o mundo da produção, pois não cremos na autonomia dos mesmos. ${ }^{67}$
\end{abstract}

Aqui está formulada, inclusive, a tese de que os movimentos sociais urbanos são socialmente inferiores ou dependentes de articulações maiores, como as da esfera políticopartidária. Autores como Carlos Nelson Ferreira dos Santos tinham o mesmo tipo de entendimento, ao contrário de Ilse Scherer-Warren, Vera da Silva Telles e Eunice Durham. ${ }^{68}$ Ao mesmo tempo, o caráter indireto da determinação dos fenômenos urbanos e a existência de diferentes mediações, mencionadas anteriormente por Gohn, abrem a possibilidade para uma razoável flexibilidade analítica e teórica. Essa mesma autora e outros deram fluidez, progressivamente, à dimensão sociológica dos movimentos sociais, numa direção crescentemente fenomenológica.

O aparecimento de reflexões que revelam um nível significativo de determinismo estrutural nas ações coletivas dos setores populares, no decurso de análises sociológicas sobre movimentos sociais urbanos, foi comum a vários estudiosos. É o que ilustra a seguinte passagem do já mencionado trabalho de Moisés e Martinez-Alier: "era inevitável que as contradições geradas pelo desenvolvimento urbano lançassem as classes populares em uma relação antagônica com o Estado." ${ }^{69}$

Todavia, tal determinismo foi detectado e problematizado pelos próprios investigadores dos movimentos sociais urbanos de então. Quando Moisés e Martinez-Alier criticaram "um mecanicismo de tipo economicista, que explicaria a política e a história (ou a superestrutura) como simples reflexo da estrutura econômica", ${ }^{70}$ estavam preocupados em evitar um mecanicismo ou determinismo marxista vulgar na análise do urbano, das contradições urbanas e de seus movimentos sociais. Na mesma linha, Durham apontou que os movimentos sociais não se desenvolveriam como defesa contra o empobrecimento

\footnotetext{
${ }^{67}$ GOHN, op. cit., p. 32.

${ }^{68}$ DURHAM, op. cit., p. 25.

${ }^{69}$ MOISÉS E MARTINEZ-ALIER, op. cit., p. 52.

${ }^{70}$ Ibidem, op. cit., p. 45.
} 
crescente. Isto é, as reivindicações surgem onde são possíveis de serem formuladas e atendidas, não onde são mais necessárias. ${ }^{71}$ Ruth Cardoso acrescentou que as carências urbanas dos setores populares não produzem espontânea ou mecanicamente a mobilização social. $^{72}$

Como fazer com que a preocupação antideterminista e antimecanicista resultasse efetiva em termos analíticos e teóricos? Voltando os olhos para a "articulação das diferentes práticas vivenciadas pelos indivíduos" nos movimentos sociais urbanos, segundo Gohn ${ }^{73}$; bem como visualizando, com os próprios Moisés e Martinez-Alier, que a cidade é construída por atores sociais agindo de acordo com seus interesses próprios: as classes dominantes, as classes populares e o Estado. ${ }^{74}$

$\mathrm{Na}$ busca das diferentes práticas de indivíduos articulando-se coletivamente em movimentos e constituindo novos atores sociais, o campo intelectual brasileiro dos anos 1970 e 80 protagonizava mudanças nos paradigmas de análise dos movimentos sociais em geral e dos movimentos sociais urbanos em particular. A perspectiva teórico-analítica centrada nas contradições urbanas, por meio do conceito de reprodução, vincula os movimentos sociais urbanos às relações de classe. Ao mesmo tempo, tais movimentos não organizam as pessoas a partir de sua inserção no processo produtivo, ao contrário, remetem à esfera do consumo. Contudo, como apontou Eunice Durham, o conceito de reprodução mostra-se restrito para explicar a heterogeneidade, a complexidade e a fluidez específicas dos movimentos sociais. Os estudos a respeito, então, caminharam em direção ao campo da cultura. Neste campo, é possível perceber o que não pode ser reduzido às necessidades relativas à reprodução. Só uma análise "de dentro" dos movimentos, observando-se privilegiadamente seus valores, práticas, iniciativas e tensões, seria capaz de forjar uma compreensão desta "nova sociedade que está se constituindo de uma forma que não obedece aos esquemas construídos no passado", ${ }^{75}$ - isto é, os esquemas de pensamento até então utilizados de modo predominante pelos intelectuais.

Uma perspectiva teórico-analítica dos movimentos sociais centrada no plano cultural propicia também, como argumentou Ruth Cardoso, o desenvolvimento de "discussões que passam pelas emoções e pela subjetividade, espaço este visto como privilegiado para a formação de um espírito coletivo". Por meio da cultura, a vivência do indivíduo enquanto negro, mulher, membro de uma comunidade etc. é mais bem visualizada e permite revelar a característica libertária dos novos movimentos sociais. ${ }^{76}$

No meu entendimento, tudo isso reforçava, no pensamento social e nas ciências sociais brasileiras de então, um encantamento com as possibilidades analíticas e teóricas abertas por uma perspectiva fenomenológica da investigação empírica dos movimentos sociais, notadamente os protagonizados pelas classes populares. Através de um paradigma

\footnotetext{
${ }^{71}$ DURHAM, op. cit., p. 25.

${ }^{72}$ CARDOSO, op. cit., p. 229.

${ }^{73}$ GOHN, op. cit., p. 26.

${ }^{74}$ MOISÉS E MARTINEZ-ALIER, op. cit., p. 46.

${ }^{75}$ DURHAM, op. cit., p. 26.

${ }^{76}$ CARDOSO, op. cit., p. 232.
} 
cultural, fornecia-se ou reconhecia-se uma muito mais significativa legitimidade teórica e analítica ao comportamento dessas classes, valorizando-se suas experiências cotidianas, espontâneas, locais, intersubjetivas e singulares - por meio de seus movimentos, notadamente.

Uma boa ilustração da análise "de dentro" dos movimentos sociais urbanos, centrada na dimensão cultural, é o mencionado trabalho de Paul Singer. Falando dos movimentos sociais urbanos estimulados pelas Comunidades Eclesiais de Base (CEBs), mostrou que eles não aceitavam que as desigualdades sociais fossem fruto de diferenças individuais, que a pobreza fosse de responsabilidade dos próprios pobres (por ignorância, baixa produtividade, alta taxa de natalidade etc.), que a carência de serviços urbanos fosse mera negligência dos governos. E concluiu:

\footnotetext{
Desta maneira, a organização que as CEBs oferecem aos movimentos de bairro se propõe a uma "démarche" ideológica completamente diferente da que inspirou o mesmo movimento durante décadas anteriores [...] [aquelas carências] são atribuídas à própria organização social capitalista. ${ }^{77}$
}

Singer, com tal valorização desse novo posicionamento ideológico, forneceu efetivamente uma fundamentação alternativa para o caráter "novo" dos emergentes movimentos sociais urbanos. Além da base cultural da fundamentação, vê-se na análise que Singer separava o que se desenvolve na dimensão da vivência dos setores populares - a solidariedade mútua, que permitiria uma partilha mais justa do esforço comum - do que é induzido por aquela organização social capitalista - o individualismo. ${ }^{78}$

Os termos "de dentro" e "de fora", quando utilizados em estudos de articulações político-sociais de setores populares, como no trabalho clássico de Barrington Moore Jr., ${ }^{79}$ revelam algum tipo de consideração especial quanto às iniciativas, formulações e experiências próprias ("de dentro") dos setores "de baixo", visto que contribuições a eles fornecidas por intelectuais, técnicos e agentes de outras instituições (mesmo o Estado) são de antemão consideradas externas ("de fora").

As análises "de dentro" dos movimentos sociais urbanos, priorizando aspectos culturais e práticos próprios de seus protagonistas, muitas vezes identificados e mesmo autoidentificados como membros de "comunidades", consubstanciavam o que chamo de posição "internalista" no debate do campo intelectual brasileiro centrado no estudo dos movimentos sociais urbanos. Em oposição a ela, temos a posição "externalista", que, para uma mais precisa e rica compreensão de tais movimentos, advogava seu estudo levando em conta uma contextualização a partir de fatores estruturais e de suas relações com a sociedade em geral, notadamente com o Estado.

Essas tendências analíticas e teóricas observáveis em intelectuais brasileiros protagonistas dos estudos sobre movimentos sociais urbanos nos anos 1970/80 perpassaram

\footnotetext{
${ }^{77}$ SINGER, op. cit., p. 91-2.

${ }^{78}$ Ibidem.

${ }^{79}$ MOORE Jr., Barrington. Injustiça: as Bases Sociais da Obediência e da Revolta. São Paulo: Brasiliense, 1987.
} 
de um modo muito amplo o pensamento social e as ciências sociais brasileiras do período. Estudiosos que muitas vezes divergiam entre si em questões relativas a esses movimentos apresentavam em seus trabalhos características similares concernentes à valorização do (que entendo como) empírico/fenomenológico ou às "tentações" deterministas e estruturalistas.

A dualidade entre análises "de dentro" e "de fora" era reconhecida e em grande medida assumida por seus protagonistas. No entanto, divergências significativas também se davam em relação aos limites e potencialidades dos movimentos sociais urbanos, sua autonomia ou heteronomia, relação com o Estado, motivações dos atores envolvidos, bem como os significados em torno da noção de comunidade. Em maior ou menor grau, questões como essas podem ser relacionadas às esperanças que nosso campo intelectual, nossas ciências sociais e a própria sociedade civil brasileira depositavam nos movimentos sociais urbanos (bem como em outros movimentos) enquanto instâncias capazes de democratizar o país.

\title{
CONCLUSÃO
}

Ao relacionar as preocupações acima referidas, então vividas por nossos atores sociais (intelectualizados ou não), com a produção intelectual do período, cito Ruth Cardoso:

\begin{abstract}
Quando começaram os estudos sobre os movimentos sociais urbanos, eles foram uma rajada de ar fresco em nossa produção sociológica. O conhecimento sobre as classes populares não havia acompanhado as transformações por que passara nossa sociedade. ${ }^{80}$
\end{abstract}

Ela afirmou que, nos anos 1970, veio à cena "uma camada popular mais participante": setores excluídos da política passaram a reivindicar maior igualdade, mesmo no contexto autoritário. Então, "estimulados pela visibilidade da presença popular", pela "sociedade civil em movimento", os cientistas sociais passaram a prestar atenção aos movimentos sociais urbanos e rurais. Multiplicavam-se os estudos sobre o tema. ${ }^{81}$

Cardoso ressaltou que tais estudiosos - que denomino "novos" intelectuais iniciaram tal percurso pelo campo popular urbano a partir das "novas contradições urbanas", conforme visto aqui. Ela lembrou que eles tinham como pano de fundo as lutas sociais dos anos 1960 - por direitos civis de negros e mulheres, o Maio de 68, a contracultura - que, por sua vez, remetiam à discussão da marginalidade e de um "novo modo de vida". Para a autora, Touraine era a referência teórica mais arrojada nesse campo de estudos, apontando uma sociedade pós-industrial, na qual o Estado tem novas formas de gestão e os movimentos sociais são os protagonistas do conflito. ${ }^{82}$

Mas Cardoso já criticava parcialmente o processo de formação e consolidação dos estudos dos movimentos sociais urbanos. Afirmou que havia "pouca discordância na

\footnotetext{
${ }^{80}$ CARDOSO, op. cit., p. 215.

${ }^{81}$ Ibidem, p. 216.

${ }^{82}$ Ibidem, p. 216 a 218.
} 
interpretação dos movimentos e associações populares". Contudo, os pressupostos dessa interpretação majoritária da época nem sempre eram explicitados, além de terem em comum um "desamparo teórico" diante das vitórias da direita autoritária, daí desenvolvendo-se as críticas ao populismo: pois fora "olhando para trás que o tema da eterna exclusão das classes populares tomou corpo e forneceu o ponto de partida para interpretar sua nova presença.". ${ }^{83}$

Assim como no campo de estudos sindicais, no Brasil, a principal referência analítica inspiradora era Francisco Weffort. A partir dele, segundo Cardoso, os "novos" intelectuais passaram a reparar que as camadas populares que enchiam comícios populistas no pré-64 reapareciam espontânea e autonomamente nos movimentos de bairro nos anos 1970. A autora lembrou que José Álvaro Moisés analisou movimentos autonomistas nos anos 1950, fazendo a ligação entre passado e presente, retomando as premissas de Weffort. ${ }^{84}$ Além disso, estes dois autores criticaram a esquerda da época por não reparar na importância dos movimentos locais dos anos 1970, por não apreender corretamente o fenômeno do populismo e por privilegiar analiticamente o ângulo das relações de produção. Moisés se preocupava com a presença popular espontânea à margem dos partidos, sendo então o espontaneísmo o inverso da manipulação populista. Weffort parecia também oscilar, criticando tanto a mistificação inerente ao populismo quanto demonstrando seu caráter ambíguo, já que o populismo conseguia expressar insatisfações populares. Mas para Cardoso, prevaleceria o viés crítico dos trabalhos dos autores que identifico como "novos" intelectuais: "O grande problema para a literatura desta época é conciliar a visão crítica do sistema representativo e a crença na força e independência do povo que deve transparecer em seu sentido político inato." E finalizou: “[...] este será o traço exaltado pelos autores mais recentes, que longe da época populista, esquecem a ambigüidade e enfatizam a mistificação." ${ }^{85}$

Ruth Cardoso também observou as tendências que dominavam o novo pensamento social brasileiro do período, muito mais propenso a criticar a experiência pré-64 e a buscar nos setores populares - em análises "de dentro", "internalistas", portanto - novos caminhos para a renovação democrática e radical de nossa sociedade, em detrimento do Estado, da política institucional, dos partidos tradicionais da esquerda. Ela alinhavou, com precisão, que análises mais abrangentes, no tempo histórico e no espaço social, tinham sido realizadas precocemente por Weffort e Moisés, mas que, posteriormente, uma perspectiva crítica mais restrita teria prevalecido.

Do ponto de vista do desenvolvimento do campo intelectual brasileiro da época, concluo em sentido contrário a Cardoso. A "descoberta" dos setores populares - uma área de estudo ainda pouquíssimo desenvolvida até então - e a identificação contundente dessa histórica lacuna em nossa reflexão sociológica provavelmente eram muito mais interessantes e estimulantes em termos de nossa produção intelectual. O boom de trabalhos dedicados à

\footnotetext{
${ }^{83}$ Ibidem, p. 220.

${ }^{84}$ Ibidem, p. 221/222. Ver também a nota 23 deste artigo.

${ }^{85}$ CARDOSO, op. cit., p. 222-223.
} 
investigação do - e aposta no - campo popular ("novos" movimentos sociais urbanos, "novo sindicalismo" etc.) significaria, a meu ver, nada mais do que "correr atrás do prejuízo", depois de tantas décadas priorizando analiticamente o Estado e os atores sociais concebidos enquanto estruturalmente determinados (pela economia e por vanguardas políticas, por exemplo). Além disso, apesar de grande parte da produção sociológica passar a se desenvolver em termos mais críticos em relação ao passado e ao "sistema representativo" (outro nome para a institucionalidade política), mesmo o reducionismo aí presente é relativo, uma vez que as investigações empíricas e de caráter fenomenológico dos "de baixo" acabaram por ampliar enormemente a riqueza e a diversidade da produção das ciências sociais no Brasil. Por isso, também o "desamparo teórico" apontado por Ruth Cardoso pode ser entendido positivamente: como uma espécie de transição teórica que se fazia no campo intelectual brasileiro. Não mais pela mera adesão de nossos cientistas sociais a tal ou qual corrente teórica oriunda de movimentos culturais internacionais ou universidades europeias e estadunidenses, mas pela interação das pesquisas, mais ou menos engajadas, desses cientistas sociais com a multifacetada realidade empírica dos "de baixo", conferindo às opções analíticas, teóricas e ideológicas daí decorrentes uma pertinência política, sociológica e subjetiva muito maior. Ao enfatizar aquele "desamparo teórico", Cardoso não explicitava devidamente a inflexão fenomenológica por que passava o campo intelectual, do qual ela mesma era uma das protagonistas.

Assim, as ciências sociais brasileiras aceleraram seu desenvolvimento a partir dos anos 1970. Superando a hegemonia althusseriana imediatamente anterior, e sua discussão sobre os aparelhos ideológicos de Estado,

\footnotetext{
alguns cientistas sociais colocaram de um mesmo lado todos os canais institucionais de manifestação política (partidos, sindicatos, etc.) e de outro os eventos independentes. Fez-se a crítica geral dos partidos (de direita e de esquerda) para recuperar as formas de expressão dos interesses políticos em sua "naturalidade", isto é, aquilo que explode nos interstícios do sistema e resiste à domesticação pelos aparelhos ideológicos. [...] Nesta linha, um dos problemas que a pesquisa deveria enfrentar é como qualificar sociologicamente essas variadas irrupções. Se elas não são vistas como expressando estritos interesses de classe, manifestam quase sempre uma reação à dominação e unem os oprimidos. Por isso, passou a ter curso a noção de classes populares que, sendo mais abrangente que o conceito de proletariado, é bastante mais imprecisa. ${ }^{86}$
}

Nessa passagem, a partir da noção de "desamparo teórico", Ruth Cardoso mencionou a imprecisa definição de classes populares, que remete a setores sociais empobrecidos pelo modelo de desenvolvimento e excluídos das decisões da política, mas capazes de distinguir suas necessidades básicas e reclamar maior igualdade. Mencionou também o uso de tal definição: quase metafórico e majoritariamente político, em torno da ideia de um "novo ator", que reivindica economicamente e também democracia. ${ }^{87}$

Eunice Durham era uma das intelectuais do período que, ainda que próxima teórica

\footnotetext{
${ }^{86}$ CARDOSO, op. cit., p. 223 (grifos no original).

${ }^{87}$ Ibidem, p. 224.
} 
e politicamente de Ruth Cardoso, via de outra forma a problemática da imprecisão conceitual sobre os "de baixo" presente nos trabalhos dos "novos" intelectuais. Ela lia essa problemática através da "questão da base de classes dos movimentos sociais", na qual era claríssima a heterogeneidade dos setores de baixa renda. Daí,

a substituição, na análise, de conceitos mais precisos como o de proletariado, por termos alusivos ou descritivos que possuem uma fundamentação teórica muito menos clara: "classes populares", "classes trabalhadoras", ou, ainda mais genericamente, "os pobres", "o povo". 88

O que extraio dessa passagem de Eunice Durham é justamente o fato de Ruth Cardoso, ao se preocupar com a precisão conceitual, estar raciocinando em termos por demais estruturais, o que impedia a abertura a percepções empíricas mais diversificadas das experiências dos "de baixo", pelo menos ao nível do discurso teórico e analítico. O que configura um típico procedimento "externalista", infenso às análises de "dentro" (microssociológicas e mais afeitas às subjetividades dos sujeitos investigados). Um bom exemplo da quase necessidade de uma imprecisão conceitual para o desenvolvimento de inovações no campo das ciências sociais do Brasil nos anos 1970/80 é dado pelo já citado trabalho de Carlos Nelson Ferreira dos Santos - por ironia, um autor mais próximo da posição "externalista" representada por Ruth Cardoso. Ao analisar lutas urbanas em regiões periféricas do Rio de Janeiro, lançou mão da categoria morador ${ }^{89}$ - mais vaga que precisa, mais delineável do que definível - para investigar os comportamentos de participantes de movimentos sociais urbanos, sem operar de modo pré-concebido em relação a eles, algo que provavelmente aconteceria se utilizasse conceitos mais consagrados (proletariado, lumpemproletariado), ao mesmo tempo, mais "recheados" de significados apriorísticos e mais vinculantes a relações estruturais e/ou abrangentes, como a discussão da reprodução social, por exemplo.

É na mesma direção que pode ser percebido o uso de termos genéricos como "classes subalternas", "classes populares" e "massas urbanas" por José Álvaro Moisés e Verena Martinez-Alier, como abaixo:

Classes subalternas, elas se encontram subordinadas aos padrões de domínio impostos pelas classes dominantes, de forma particular o domínio do Estado. Entretanto, no caso brasileiro, contrariamente ao que acontece na maioria dos países capitalistas, essas classes populares não são dotadas de organizações próprias de defesa econômica e de representação política diante do Estado e das demais classes sociais, o que as restringe para expressar a sua presença na sociedade de forma autônoma e independente. Isso torna muito mais difícil para os analistas - e para seus próprios protagonistas - perceberem a sua presença social e política de forma positiva, isto é, a manifestação de seu querer e de sua vontade própria como algo distinto e específico no interior da história social, em grande parte dirigida e disseminada pelas elites dominantes. Dir-se-ia que, 'massa atrasada', essas classes populares não têm história, são os grandes ausentes das

\footnotetext{
${ }^{88}$ DURHAM, op. cit., p. 26.

${ }^{89}$ SANTOS, op. cit., p. 328.
} 
mudanças profundas que têm ocorrido na sociedade brasileira desde o início da década de 60. Além disso, nas condições do regime autoritário instaurado desde 1964 , com a repressão que se abateu mesmo às suas organizações classistas diretamente controladas pelo Estado, como é o caso dos sindicatos, e com a destruição de seu único poder de relativa barganha diante do bloco de poder - que é como se caracteriza o voto durante a democracia populista de massas - tudo parecia indicar que essas massas urbanas estavam completamente alijadas da vida política nacional. Na verdade, não faltou quem, entre os críticos do regime autoritário e os que aspiravam representá-las, imaginasse poder substituí-las e até realizar por elas as tarefas históricas que lhes são imputadas. ${ }^{90}$

Assim, consoante a leitura aqui desenvolvida a respeito da inflexão fenomenológica no pensamento social brasileiro dedicado aos atores sociais de extração popular, Moisés e Martinez-Alier se propuseram, especificamente, a

tomar, como ponto de partida, as situações concretas constitutivas do cotidiano das classes populares, como princípio metodológico. Isso garantirá que, durante a análise, a ação dessas classes, qualquer que seja o seu caráter, não será desqualificada e, portanto, isolada do próprio processo analítico. ${ }^{91}$

Na perspectiva das pequenas reflexões aqui presentes, pode-se concluir da seguinte maneira: mais do que um paradigma fechado relativo aos movimentos sociais urbanos - que se dava em função de disputas inerentes ao campo intelectual, relativas à inauguração dessa nova frente de estudos nas ciências sociais brasileiras -, as análises mais centradas nas microexperiências, singulares e subjetivas, internas aos setores "de baixo" de nossa sociedade, deixaram marcas inegáveis tanto em nossa democracia como na intelectualidade brasileira, na medida em que estabeleceram parâmetros menos elitistas e mais complexos para se perceber as articulações de nossa sociedade civil e, principalmente, do campo popular.

A especial atenção para o "fazer-se", na acepção thompsoniana, ${ }^{92}$ das classes populares brasileiras, por meio de suas experiências de luta nos diversos movimentos sociais (tão vigorosos no período), em detrimento das considerações, por vezes teoricistas, a respeito dos eixos - econômico, político, ideológico - determinadores dos comportamentos dessas mesmas classes, pode ser analisada como evidência da maior sensibilidade fenomenológica e empírica de nosso campo intelectual diante daquilo que passou a identificar como "novo" na trajetória histórica da sociedade brasileira e seus setores tradicionalmente subalternizados.

Recebido em 10/05/2012

Aceito para publicação em 15/06/2012

\footnotetext{
${ }^{90}$ MOISÉS e MARTINEZ-ALIER, op. cit., p. 19 (grifos no original).

${ }^{91}$ Ibidem, op. cit., p. 20.

92 Em relação à influência dos trabalhos de E. P. Thompson nos estudos relativos aos "novos" movimentos sociais urbanos e ao "novo sindicalismo", ver meu livro anteriormente citado, especialmente p. 66-70 e 148-70.
} 